\title{
Earthworms and root-knot nematodes: effect on soil biological activity and tomato growth
}

\section{Minhocas e nematoides das galhas: efeitos na atividade biológica do solo e crescimento do tomate}

\author{
Wilian Carlo Demetrio ${ }^{1 *}$; Jair Alves Dionísio²; Arlei Maceda ${ }^{3}$
}

\begin{abstract}
Earthworms are a representative soil invertebrate, and their living habits are known to influence a large diversity of organisms. The objective of this study was to evaluate the ability of Amynthas spp. to change the biological attributes of soil, and its potential to reduce infection by root-knot nematodes on tomato crop. The study was conducted in the greenhouse of the Diagnostic Center Marcos Enrietti, Federal University of Paraná, Brazil. The treatments earthworms at the following densities: control (absence of earthworms), two, four, six, and eight, which were inoculated into different pots, with five replicates per group. In each pot, a single tomato plant (Solanum lycopersicum) was used, and a suspension of Meloidogyne javanica containing 3000 eggs and/or juveniles was added 14 days after seeding. During the experiment, edaphic respiration was evaluated at 96-h intervals. After 91 days, soil microbial biomass carbon (MBC), microbial soil respiration (MSR), the metabolic quotient $\left(q \mathrm{CO}_{2}\right)$, dry mass of roots (DMR), dry mass of plants (DMP), and the number of root galls were determined per plant. We observed that inoculation with higher earthworm densities increased the MBC. Furthermore, the lowest earthworm density (two animals) resulted in a MBC that was $75 \%$ higher than that of the control treatment (earthworms absent). There was a positive correlation between MBC and DMP, and a negative correlation between $\mathrm{MBC}$ and $q \mathrm{CO}_{2}$. The DMR was not influenced by inoculation with earthworms. A linear increase in DMP was observed with earthworms; however, gall formations on the tomato root were not suppressed.
\end{abstract}

Key words: Amynthas spp. Edaphic respiration. Meloidogyne javanica. Microbial biomass.

\section{Resumo}

As minhocas são um dos mais representativos invertebrados do solo e sabe-se que seus hábitos de vida influenciam uma grande diversidade de outros organismos. O objetivo deste estudo foi avaliar a capacidade de Amynthas spp. em alterar alguns atributos biológicos do solo e seu potencial em reduzir a infecção de nematoides formadores de galhas na cultura do tomate. O estudo foi conduzido em casa de vegetação no Centro Diagnóstico Marcos Enrietti, Universidade Federal do Paraná, Brasil. Os tratamentos foram diferentes densidades de minhocas: Controle (ausência de minhocas), dois, quatro, seis e oito indivíduos inoculados por vaso, com cinco repetições. Em cada vaso foi utilizada uma única plântula de tomate (Solanum lycopersicum), onde, aos 14 dias após a semeadura foi adicionada uma suspensão contendo 3000 ovos e/ou juvenis de Meloidogyne javanica. Durante o experimento,

' Discente, Curso de Doutorado, Programa de Pós-Graduação em Ciência do Solo, Universidade Federal do Paraná, UFPR, Curitiba, PR, Brasil. E-mail: wiliandemetrio@hotmail.com

2 Prof. Dr., Departamento de Solos e Engenharia Agrícola, UFPR, Curitiba, PR, Brasil. E-mail: jair@ufpr.br

3 Eng ${ }^{\circ}$ Agr $^{\circ}$, M.e, Agência de Defesa Agropecuária do Paraná, ADAPAR, Curitiba, PR, Brasil. E-mail: arleimaceda@adapar. pr.gov.br

* Author for correspondence 
a respiração edáfica foi avaliada em intervalos de 96 horas. Após 91 dias, o carbono da biomassa microbiana (MBC), respiração microbiana (MSR), quociente metabólico $\left(q \mathrm{CO}_{2}\right)$, massa seca das raízes (DMR), massa seca da planta (DMP) e o número de galhas por planta foram determinados. Como resultados, observou-se que a inoculação de altas densidades de minhocas aumentou o MBC. Além disso, baixas densidades de minhocas (dois indivíduos) mostraram valores de MBC 75\% maiores, comparados ao tratamento controle (ausência de minhocas). Houve uma correlação positiva entre MBC e DMP, negativa entre $\mathrm{MBC}$ e $q \mathrm{CO}_{2}$. A DMR não foi influenciada pela inoculação de minhocas. Um aumento linear da DMP foi observado com o aumento da densidade de minhocas, sem ocorrer supressão da formação de galhas nas raízes.

Palavras-chave: Amynthas spp. Biomassa microbiana. Meloidogyne javanica. Respiração edáfica.

\section{Introduction}

Earthworms are edaphic animals, known as "ecosystem engineers", which are a group of animals able to alter the environment in which they live, can represent up to $80 \%$ of the biomass of soil organisms (LAVELLE et al., 1997).

The feeding behaviour of earthworms is diverse, ranging from detritivores to geophagous organisms (EDWARDS; BOHLEN, 1996). The former are responsible for the decomposition of organic waste, while the latter are responsible for the spatial displacement of organic and mineral particles in the soil profile, thus, changing the availability of food to other soil animals, especially the microbial community (BROWN et al., 2000).

The action of earthworms in soil is known to change microbial biomass and the activity of microorganisms (AIRA et al., 2007; BROWN et al., 2006 as well as soil respiration (HÖGBERG; READ, 2006). In addition, these animals can promote changes in the chemical $(\mathrm{pH}$ and nutrient availability) and physical (water retention capacity, infiltration, aeration, and soil structure) properties. Earthworms are saprophytic and feed on dead organic matter, and do not usually pose any detrimental effects to plant roots (BROWN et al., 1995). Additionally, they are capable of interacting with the edaphic microfauna, such as nematodes, protozoa, and rotifers, which can be ingested together with the soil because of the feeding habits of the oligochaetes (EDWARDS; BOHLEN, 1996).

Nematodes represent a large portion of the soil microfauna. The Meloidogyne genus is characterised as a phytonematode because of its feeding behaviour, and is known to parasite plants and induce gall formation (MOENS et al., 2009). In Brazil, nematodes that form galls are responsible for losses in grain crops, oilseeds, fruit, and ornamental plants (MOREIRA; FERREIRA, 2015).

Many management practices have been employed to control nematodes, such as the use of non-host plants of these organisms during crop rotation and the solarisation of soil. However, the effectiveness of such management practices is limited, mainly due to the high resilience of these animals (MÔNACO et al., 2008; RADWAN et al., 2012 Moreover, the use of chemical nematicides, in addition to being expensive, could result in soil and environment contamination and cannot be used in organic production systems (NEVES et al., 2009).

The tomato (Solanum lycopersicum) is one of the most produced vegetables in Brazil and in the world. The Paraná, State South Brazil, is the 4th largest domestic producer of tomato (IBGE, 2015). This culture is sensitive to nematode attack, and losses due to the partial loss of root function range from 14 to 44\% (BELAN et al., 2011; CHARCHAR; ARAGÃO, 2005).

Little is known about the potential suppression of nematodes by earthworms. Lafont et al. (2007) studied the interaction between Pontoscolex corethrurus and nematodes of the Radopholus genus. They observed that the presence of earthworms did not reduce the number of nematodes on the banana 
root system, but enhanced plant growth. Moreover, some studies have reported significant results using Eisenia andrei, including the reduction in the nematode population in a vermicomposting system (DOMÍNGUEZ et al., 2003). A 51\% reduction in the nematode population in soil was observed following the addition of Lumbricus rubellus (ILIEVA-MAKULEC; MAKULEC, 2002). In Brazil, a study by Dionísio et al. (2014) showed a reduction of more than $50 \%$ in the total number of nematode galls (Meloidogyne paranaensis) on tomato roots, using Amynthas spp.

The objective of the present study was to evaluate the ability of Amynthas spp. to suppress the parasite population of nematodes, and to examine the extent of the impact of these earthworms on soil biological activity and tomato growth.

\section{Material and Methods}

The study was conducted in a protected environment at the Diagnostic Center Marcos Enrietti, located in the Sector of Agricultural Sciences - Federal University of Paraná (UFPR). A Cambisol clay loam texture soil was used as the substrate (EMBRAPA, 2013). Initially, the soil was sieved (4-mm mesh) and sterilised in a steam oven, at approximately $100^{\circ} \mathrm{C}$ for $3 \mathrm{~h}$, then packed in plastic polyethylene pots. The substrate was characterised as follows: $\mathrm{pH}$ of $5.70 \mathrm{CaCl}_{2} 0.01 \mathrm{M}$; exchangeable cations $\left(\mathrm{cmol}_{\mathrm{c}} \mathrm{dm}^{-3}\right) \mathrm{Ca} 8.40, \mathrm{Mg} 4.80$, and $\mathrm{K} 1.07$; $\mathrm{P}\left(\mathrm{mg} \mathrm{dm}{ }^{-3}\right)$ 43.9; $\mathrm{C}\left(\mathrm{g} \mathrm{dm}^{-3}\right) 33.3$; and V (\%) 76; and physical $\left(\mathrm{g} \mathrm{kg}^{-1}\right)$; sand 420 , silt 305 , clay 275 ; and water retention capacity $38 \%$. The experimental setup was divided in two stages as described below.

\section{Stage 1 - Production of M. javanica inoculum}

Seedlings of tomato (S. lycopersicum, variety Santa Cruz Kada Paulista) were produced in $250 \mathrm{~mL}$ plastic pots, containing the commercial substrate pine bark Mecplant ${ }^{\mathbb{}}$, biostabilised, homogenised with $<2-\mathrm{mm}$ particles without fertiliser, and sterilised. At 14 days after emergence (DAE), the plants were transplanted to plastic pots (PP) with a volume of $4 \mathrm{~L}$, containing $3 \mathrm{~kg}$ of soil. One week later, plants were inoculated with an aqueous suspension containing eggs and/or juveniles (no count) of the nematode $M$. javanica. The plants were left for approximately 180 days for inoculum production.

\section{Stage 2 - Experiment}

The experiment was conducted in a completely randomised design using earthworm density as the main factor, with five treatments $\mathrm{T} 1=0, \mathrm{~T} 2=2, \mathrm{~T} 3$ $=4, \mathrm{~T} 4=6$, and $\mathrm{T} 5=8$ earthworms (Amynthas spp.) per pot and five replicates. The experimental units (EU) were each represented by a 4-L PP, containing $3 \mathrm{~kg}$ of soil and a single inoculated adult worm.

The adult animals were collected manually in the UFPR Sector of Agricultural Sciences, and were selected by the presence of clitellum and identified to genus level (SIMS; GERARD, 1999). The earthworms were rinsed with deionised water, dried with paper towels, and fresh biomass (FBE) was recorded. FBE $(\mathrm{g})$ used in the treatments T2, T3, T4, and T5 was $2.616 \pm 0.208 ; 4.959 \pm 0.3688$; $7.687 \pm 0.9776$, and $9.512 \pm 0.3984$, respectively.

Each EU was kept for 10 days covered with nonwoven fabric, to ensure the acclimatisation of earthworms, preventing them from escaping, and allowing deaths to be verified and animals to be replaced, if necessary. After acclimatisation, the tomato variety Santa Cruz Kada Paulista was sowed in PP, and then thinned at $14 \mathrm{DAE}$, leaving one plant per pot.

The nematodes were inoculated onto plants 3 days after thinning. Each EU received an aqueous suspension containing 875 eggs and/or juveniles of $M$. javanica, which were obtained according to the methodology described by Bonetti and Ferraz (1981). M. javanica were mashed in a blender with $\mathrm{NaClO}$ solution $(0.5 \%)$ and sifted $(0.075$ and 0.025 
$\mathrm{mm})$. Nematodes were counted under an optical microscope (25× amplification). Each EU was inoculated with $3.5 \mathrm{~mL}$ of the solution containing M. javanica, which were distributed in three $1-\mathrm{cm}$ holes on the stem of plants.

During the experiment, the plants received daily irrigation, pruning, and nitrogen fertilisation in line with CQFS-RS/SC recommendations (SBCS, 2004). At the end of the experimental period (91 days), the plant stem was cut to $1 \mathrm{~cm}$ above the soil surface and dried at $65^{\circ} \mathrm{C}$ to determine weight.

The remaining earthworms in each EU were collected manually, washed with deionised water, and used to quantify fresh biomass. From each EU, $400 \mathrm{~g}$ of soil was collected and stored at $2-4{ }^{\circ} \mathrm{C}$ for analysis of microbial biomass carbon (MBC) and microbial soil respiration (MSR).

The roots were separated from the soil by rinsing with water and kept in a biochemical oxygen demand (BOD) incubator at $2 \pm 0.5^{\circ} \mathrm{C}$ to preserve plant tissues until galls were counted using a stereomicroscope ( $4 \times$ increase). Finally, the roots were dried at $65^{\circ} \mathrm{C}$, and the mass was determined.

Edaphic respiration (ER) was determined using the methodology described by Grisi (1978), with adaptations. This methodology is based on the $\mathrm{CO}_{2}$ emitted per area; for this, a respirometer (300-mL plastic cup) was used with another plastic container (PC) inside $(50 \mathrm{~mL})$, fixed $3 \mathrm{~cm}$ above the ground, containing $\mathrm{NaOH}\left(0.5 \mathrm{~mol} \mathrm{~L}^{-1}\right)$. The plastic containers were replaced at every reading, at 96-h intervals, and the temperature inside the EU was determined at a depth of $1 \mathrm{~cm}$.

The ER was estimated by back titration $(\mathrm{HCl} 0.5$ mol L-1) of $\mathrm{NaOH}$ excess along with $\mathrm{BaCl}_{2}(50 \%)$, and phenolphthalein $(0.1 \%)$. The $\mathrm{C}-\mathrm{CO}_{2}$ emitted per unit surface area was calculated according to the method described by Anderson (1982).

The MBC was determined by the substrateinduced respiration (SIR) method, as described by Anderson and Domsch (1978). From each sample,
$50 \mathrm{~g}$ of dry soil was weighed and transferred to 1-L plastic containers (PCo), after which an aqueous solution (60 $\mathrm{mg}$ glucose) was added to increase the humidity to $40 \%$ of the water retention capacity of the soil. The PCo was tightly closed and preincubated for $2 \mathrm{~h}$ in an incubator at $22^{\circ} \mathrm{C}$. After each one received a $\mathrm{PC}$ containing $10 \mathrm{~mL}$ of $\mathrm{NaOH}\left(0.5 \mathrm{~mol} \mathrm{~L}^{-1}\right)$, they were incubated under the same conditions for at least $4 \mathrm{~h}$. At the end of the incubation period, the samples were titrated as described for the ER, and the MBC was estimated according to the method described by Höper (2006).

The MSR was determined as described by Alef (1995), with some modifications, in a static system using a PCo containing a 50-g sample of soil (dried) moistened to $40 \%$ field capacity. A test tube containing $10 \mathrm{~mL}$ of deionised water was placed into the PCo to maintain indoor humidity and prevent the sample drying, together with 50$\mathrm{mL}$ PC containing $10 \mathrm{~mL}$ of $\mathrm{NaOH} 0.5 \mathrm{~mol} \mathrm{~L}^{-1}$. The samples were incubated at $25^{\circ} \mathrm{C}$ for $168 \mathrm{~h}$, and the excess $\mathrm{NaOH}$ was titrated as described for ER and MRS, and estimated according to the method described by Stotzky (1965).

The metabolic ratio $\left(q \mathrm{CO}_{2}\right)$ was determined using the estimated values for MBC and MRS, as described by Anderson and Domsch (1993) to determine the ratio of MRS/MBC.

The data obtained for the analysed variables were subjected to an extreme value test (Grubbs) to detect outliers. Subsequently, normality was assessed using Shapiro-Wilk test and homogeneity of variance was determined using Bartlett's test. Pearson correlation analysis and regression $(\mathrm{p}<0.05)$ were applied to all variables. Model selection was based on the significance of the regression coefficients and the higher value of the determination coefficient.

\section{Results and Discussion}

ER showed a linear response in $54.5 \%$ of the readings (Table 1), demonstrating a positive 
correlation with increasing earthworm density. This increase can be attributed to several factors, including soil burrowing by the animals, improvements in gas exchange in the soilatmosphere system, which increase the $\mathrm{O}_{2}$ flow, and facilitation of respiration by the roots (LI et al., 2002). Moreover, the presence of these animals also stimulates the activity of soil microorganisms (SIMEK; PIZL, 2010) which may contribute more than $70 \%$ of the total ER $\mathrm{CO}_{2}$ (ZHAO et al., 2013). The main effects of this stimulus probably occurred at depth (SIMEK; PIZL, 2010), where low activity has been observed compared with the surface layer (SANTOS et al., 2004).

Table 1. Regression analysis of soil respiration and different numbers of earthworms (Amynthas spp.) in the presence of nematodes (Meloidogyne javanica) on tomato crop (var. Santa Cruz Kada Paulista).

\begin{tabular}{ccccc}
\hline Date & Read $^{0}$ & Equation & $\mathrm{r}^{2}$ & $\mathrm{CV} \%$ \\
\hline $12 / 09 / 2014$ & 1 & $\mathrm{y}=20.20+0.60 \mathrm{x}$ & $0.90^{* *}$ & 10.22 \\
$15 / 09 / 2014$ & 2 & $\mathrm{y}=19.48+0.70 \mathrm{x}$ & $0.98^{* *}$ & 9.05 \\
$19 / 09 / 2014$ & 3 & $\mathrm{~ns}$ & $\mathrm{~ns}$ & 13.53 \\
$24 / 09 / 2014$ & 4 & $\mathrm{~ns}$ & $\mathrm{~ns}$ & 12.07 \\
$28 / 09 / 2014$ & 5 & $\mathrm{y}=19.44+1.23 \mathrm{x}$ & $0.89^{*}$ & 8.00 \\
$02 / 10 / 2014$ & 6 & $\mathrm{y}=23.53+0.42 \mathrm{x}$ & $0.95^{*}$ & 10.16 \\
$06 / 10 / 2014$ & 7 & $\mathrm{~ns}$ & $\mathrm{~ns}$ & 13.70 \\
$10 / 10 / 2014$ & 8 & $\mathrm{y}=35.48+0.38 \mathrm{x}$ & $0.83^{* *}$ & 5.06 \\
$14 / 10 / 2014$ & 9 & $\mathrm{~ns}$ & $\mathrm{~ns}$ & 9.60 \\
$19 / 10 / 2014$ & 10 & $\mathrm{~ns}$ & $\mathrm{~ns}$ & 13.53 \\
$25 / 10 / 2014$ & 11 & $\mathrm{y}=60.65-4.38 \mathrm{x}$ & $0.95^{* *}$ & 8.98 \\
\hline
\end{tabular}

$r^{2}-$ Coefficient of determination.

$\mathrm{CV}$ - Coefficient of variation.

$* *$, $*$ Significance at $\mathrm{p}<0.01$ and $\mathrm{p}<0.05$, respectively.

ns - non-significant.

The increased ER by the earthworms remained over 32 days ( 1 st to 8 th reading) (Figure 1), after which an inversion in the relationship occurs. After this, a significant difference $(\mathrm{p}<0.05)$ was only observed at the 11th reading ( $p<0.01)$, when the increased number of earthworms resulted in lower $\mathrm{CO}_{2}$ values. The action of the worms is important for the formation of soil aggregates (MARHAN et al., 2007), which protect organic material from attack by microorganisms (SOLLINS et al., 1996). Aggregate formation occurs due to cast production, whereby a soil mass passes through the digestive tract of the earthworms (BOSSUYT et al., 2005), especially Amynthas spp., which then deposit these casts inside the soil (SNYDER et al., 2009). 
Figure 1. Edaphic respiration by earthworm number in each pot (Amynthas spp.) and nematodes (Meloidogyne javanica) on tomato crops (var. Santa Cruz Kada Paulista).

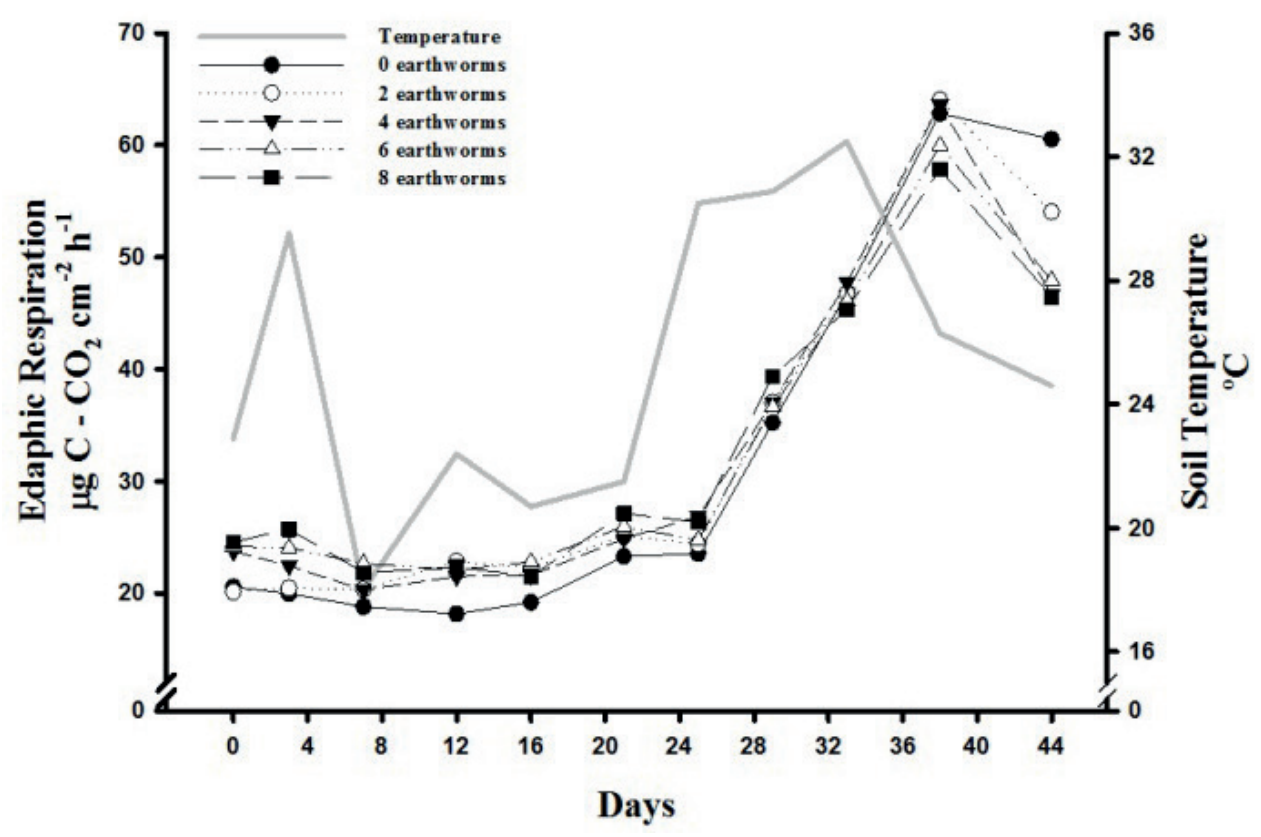

The remaining proportion of earthworms (39\%) at the end of the experiment was less than that found by Stephens and Davoren (1997)grown in a red-brown earth soil artificially infested with $\mathrm{R}$. solani, was examined. In soil artifically infested with R. solani on wheat chaff, the presence of A. trapezoides (at a number equivalent to $300 \mathrm{~m}(-2$ and Du et al. (2014), who found values above 70\%. These values occurred because of the escape and/ or death of earthworms during the experiment, probably between the 8 th and 11 th readings, which occurred when the air temperature exceeded $30^{\circ} \mathrm{C}$. The optimal temperature for $A$. gracilis survival ranged from 21 to $26^{\circ} \mathrm{C}$ (SELDEN et al., 2005). In the present study, the soil moisture was adjusted daily, and the soil temperature was the limiting factor for earthworm survival. The accumulated soil respiration (Figure 2a) did not differ statistically between treatments $(p<0.05)$.

The MBC showed quadratic adjustment (Figure $2 \mathrm{~b}$ ) depending on the number of earthworms added to the soil. The lowest and highest MBC ( $\mu \mathrm{g} \mathrm{C} \mathrm{g}^{-1}$ soil) values were 748.5 and $1582.8 \mu \mathrm{g} \mathrm{C} \mathrm{g}^{-1}$ soil for $\mathrm{T} 4$ and $\mathrm{T} 1$, respectively. Regression analysis showed that the maximum MBC, 1547.4 $\mu \mathrm{g} \mathrm{C}$ $\mathrm{g}^{-1}$ soil, occurred with 5.2 earthworms per EU, after which the MBC decreased due to elevated earthworm population.

Inoculation with two earthworms per EU (T1) caused the $\mathrm{MBC}$ to increase by more than $75 \%$ when compared to treatment without the addition of earthworms (T0). This was also observed by Burtelow et al. (1998)common in many forests of the southeastern US, are invading new habitats in north of their reported range in the northeastern US. At the Cary Arboretum in Millbrook, NY (approximately 42 $\mathrm{lu} 00 \mathrm{~b} 0 \mathrm{~N}$ latitude, 74/u00b0 $\mathrm{W}$ longitude who evaluated the invasion of Aporrectodea sp. in forests, and found that low densities (50-100 individuals $\mathrm{m}^{-2}$ ) caused a 1.4fold increase in the MBC when compared with the sites without earthworms. Results similar to those obtained with the T4 treatment (six earthworms per pot) were reported by Al-Maliki and Scullion (2013) by inoculation with Lumbricus terrestris versus the control treatment. 
The increased MBC may be due to the increased $\mathrm{NH}_{4}^{+}$concentrations inside the casts, which may be 5-15-times higher than those in the surrounding soil (DECAËNS et al., 1999). These concentrations vary depending on the feeding habits of earthworms (geophagous or detritivores) and the quality of ingested material (AIRA et al., 2003), which can stimulate and increase the microorganism population. Nitrogen is the main limiting nutrient for the development of microbial biomass (HARTMAN; RICHARDSON, 2013); consequently, the community of microorganisms accompanying the fluctuation of this nutrient (HUANG et al., 2013).

Figure 2. Regression analysis of (a) accumulated edaphic respiration, (b) microbial biomass carbon, (c) microbial soil respiration, (d) metabolic quotient, and (e) dry mass of plants with earthworm number (Amynthas spp.) per pot in the presence of Meloidogyne javanica. Bars represent standard errors.
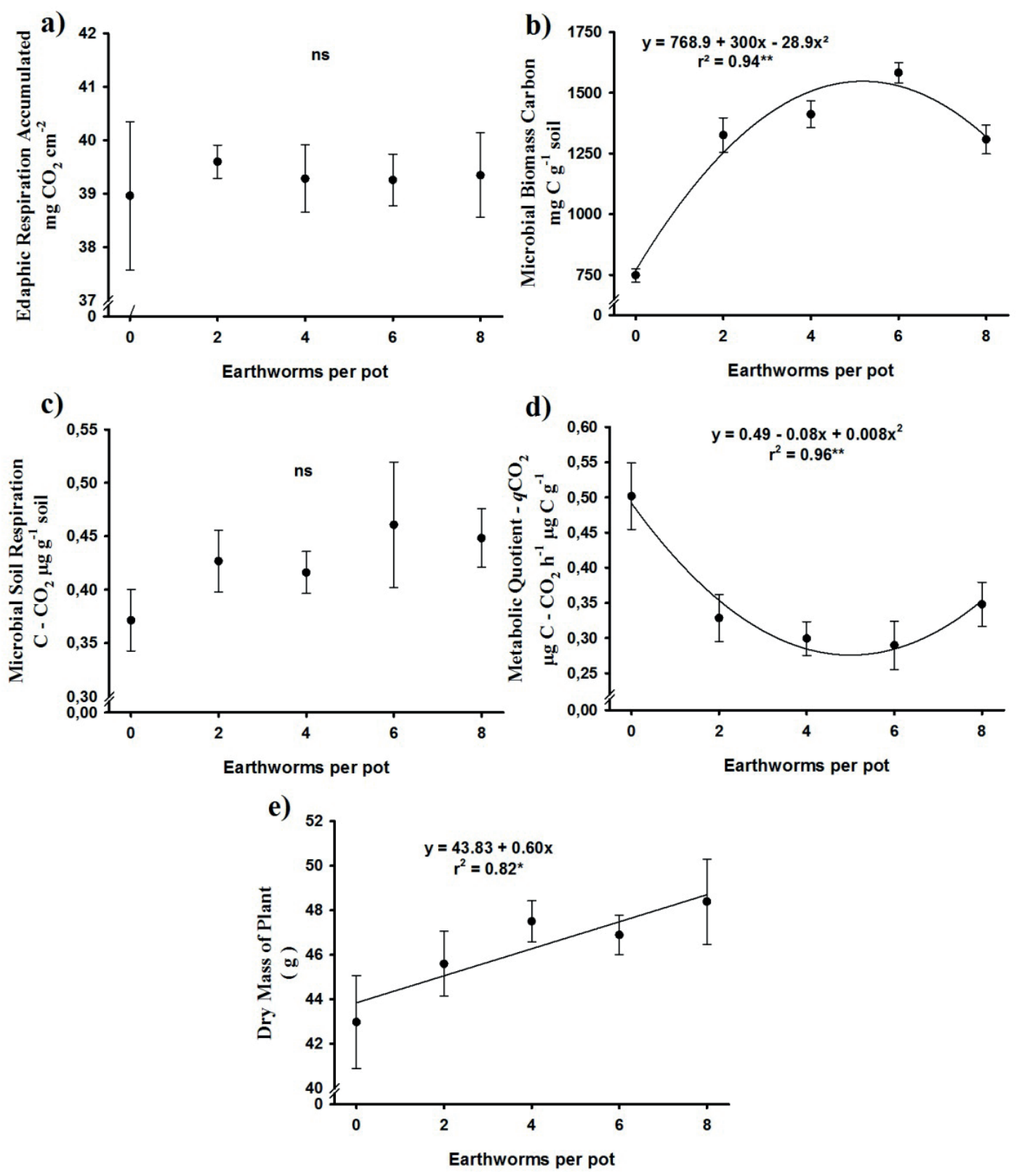

\footnotetext{
$* *$, Significance at $\mathrm{p}<0.01$ and $\mathrm{p}<0.05$, respectively. ns - non-significant.
} 
Galleries formed by earthworms also represent a good source of nitrogen for the microbial community. Parkin and Berry (1999) observed that the drilosphere $(1-2 \mathrm{~mm}$ from the wall of the galleries) contained $26.6 \mu \mathrm{g} \mathrm{N} \mathrm{g}^{-1}$ as $\mathrm{NO}_{3}^{-}$, while the adjacent soil contained only $18.8 \mu \mathrm{g} \mathrm{N} \mathrm{g}^{-1}$. This could be related to the mucus produced by the earthworms, which is rich in sugars and is released during movement (BROWN et al., 2000).

An increase in the MBC by the earthworms was also observed by Li et al. (2002), who attributed this effect to the redistribution of resources at depth, such as organic matter and $\mathrm{O}_{2}$, increasing the availability for microorganisms.

In the present study, the increase in MBC was not linear, because the T5 treatment (eight earthworms per EU) resulted in values similar to those observed with the T2 treatment (two earthworms per EU), which was $75 \%$ higher than those found in the T1 treatment (zero earthworms per EU). This can be explained by the limited resources available in the experimental unit, such as $\mathrm{C}$ and $\mathrm{N}$, due to the low availability of soil organic matter for microorganisms, resulting from aggregates formed by the earthworms (MUMMEY et al., 2006). The escape and/or death of the earthworms throughout the experiment due to the high temperature may also have contributed to the results observed for MBC.

The values obtained for MSR (Figure 2c) ranged from 0.37 to $0.46 \mu \mathrm{g} \mathrm{C}-\mathrm{CO}_{2} \mathrm{~g}^{-1} \mathrm{~h}^{-1}$ for treatments $\mathrm{T} 1$ and $\mathrm{T} 4$, respectively, with no significant differences between the treatments $(p<0.05)$. This is in contrast to the values reported by Binet et al. (1998), who observed increases in excess of $100 \%$ following inoculation with $L$. terrestris.

The lack of differences in the concomitant increase in MSR with MBC in the present study, cannot indicate low microbial activity. Increased $\mathrm{C}-\mathrm{CO}_{2}$ evolution by the microbial community may mean that individuals are working in conditions that are not ideal for their metabolism, resulting in a greater loss of soil $\mathrm{C}$ to the atmosphere (PÔRTO et al., 2009). The increase in MBC is often positively correlated with the MSR (BALOTA et al., 1998; PÔRTO et al., 2009). However, D'Andréa et al. (2002) evaluated the impact of management systems on the microbial community, and observed that even with a variation of $200 \%$ in MBC between the systems, the MSR remained unchanged, which probably indicated a change in the composition of microorganisms (ANDERSON; DOMSCH, 1993).

Quadratic adjustment was observed for the relationship between MBC and MSR, the metabolic quotient $\left(q \mathrm{CO}_{2}\right)$, (Figure $2 \mathrm{~d}$ ) based in the number of earthworms added, with data ranging from

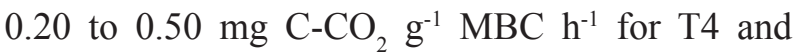
$\mathrm{T} 1$, respectively. Regression analysis showed a minimum point for $q \mathrm{CO}_{2}$ of $0.29 \mathrm{mg} \mathrm{C}-\mathrm{CO}_{2} \mathrm{~g}^{-1}$ $\mathrm{MBC} \mathrm{h}^{-1}$ in response to five Amynthas spp. per EU, after which this parameter increases as a function of the higher number of earthworms, confirming the reduction in the $\mathrm{MBC}$.

The data obtained in the present study show that the $\mathrm{T} 4$ treatment (six earthworms per EU) increased the MBC while maintaining or reducing metabolic activity, indicating that the presence of earthworms did not affect microbial activity. According to Anderson and Domsch (1993), $q \mathrm{CO}_{2}$ considers the amount of $\mathrm{CO}_{2}$ emitted by the soil per $\mathrm{C}$ unit present in the MBC; therefore, lower values indicate that the microbial community is more efficient at fixing $\mathrm{C}$ in their cells, with higher values observed in young systems, which are still in transition or are disturbed. These findings are not consistent with those by Eisenhauer et al. (2011), who evaluated the impact of exotic worm invasion (Dendrobaena octaedra, Lumbricus rubellus, Aporrectodea spp.) and showed that the composition of the soil microbial community was altered.

The $q \mathrm{CO}_{2}$ behaviour observed in the present study suggests that the earthworms altered the composition of soil microorganisms by stimulating fungal populations; this was also observed by Aira et al. (2007). These microorganisms represent the 
major component of microbial biomass, because of their morphological structure, with long hyphae and large diameter (MOREIRA; SIQUEIRA, 2006). Thus, the soil carbon may be used for the formation of cellular material, building up in the microbial biomass.

The DMP responded positively to increased levels of earthworms (Figure 2e). The highest value obtained for DMP was $48.38 \mathrm{~g} \mathrm{plant}^{-1}$, which was observed in the $\mathrm{T} 5$ treatment (eight earthworms per $\mathrm{EU})$, and the lowest value was 42.97 g plant $^{-1}$ with the control treatment (zero earthworms per EU). This represented an increase of $11.2 \%$, resulting from improvements in the chemical, physical, and biological properties of soil promoted by the action of earthworms (BROWN et al., 2006).

Worms lead to physical changes in soil as a result of the galleries, which are commonly used in the growth of plant roots and facilitate water infiltration (YVAN et al., 2012)it is often claimed that earthworm activity could alleviate soil compaction in these systems. To put this assumption to the test, an experimental compaction event was carried out on one plot of arable land. The abundance and biomass of earthworms were evaluated in compacted (under wheel tracks. Chemical changes in the presence of earthworms may have influenced the DMP, due to the increased availability of nutrients, particularly $\mathrm{P}$ and $\mathrm{N}$, through accelerated nutrient cycling. Parkin and Berry (1999) reported that the continuous deposition of $\mathrm{NH}_{4}^{+}$through the action of earthworms with cast production, stimulates nitrifying bacteria, increasing the availability of nitrogen to plants.

Physico-chemical changes alter the biological components of soil, mainly by stimulating microorganisms (BROWN et al., 2000), which can be reflected in the colonisation of roots by mycorrhizal fungi (AGHABABAEI et al., 2014) and increased nutrient absorption, especially phosphorus. Other effects include the development of plant growth-promoting bacteria (LI et al., 2002), such as Pseudomonas spp., which produce siderophores and increase the availability of $\mathrm{Fe}^{2+}$ to the plants (COELHO et al., 2007); or in the production of antibiotics, which inhibit the effects of clinical and subclinical pathogens (FREITAS, 2007).

There was a positive correlation between MBC and DMP (Table 2), reinforcing the importance of MBC in plant development. Similar results were observed by De Graaff et al. (2006), who attributed this effect to accelerated nutrient cycling, increasing the availability to plants. There was a negative correlation between $q \mathrm{CO}_{2}$ and $\mathrm{MBC}$. These results indicate that greater $\mathrm{CO}_{2}$ was lost from the system with the lower $\mathrm{MBC}$, probably due to stress preventing the full development of microorganisms, and resulting in higher metabolic activity (GRAHAM et al., 2002). In addition, a negative correlation between $q \mathrm{CO}_{2}$ and DMP suggests that the stress observed in the MBC may also affect plant development (SILVA JÚNIOR et al., 2006).

Table 2. Pearson's correlations among microbial soil respiration (MSR), microbial biomass carbon (MBC), dry mass of plants (DMP), dry mass of roots (DMR), edaphic respiration accumulated (ERA), and metabolic quotient $\left(q \mathrm{CO}_{2}\right)$.

\begin{tabular}{ccccccc}
\hline Variables & MSR & MBC & DMP & DMR & ERA & $q \mathrm{CO}_{2}$ \\
\hline MSR & 1.00 & -0.25 & -0.13 & -0.04 & -0.03 & 0.36 \\
MBC & & 1.00 & $0.44^{*}$ & 0.18 & -0.14 & $-0.78^{* *}$ \\
DMP & & & 1.00 & 0.25 & -0.13 & -0.56 \\
DMR & & & 1.00 & -0.12 & -0.22 \\
ERA & & & & 1.00 & 0.02 \\
\hline
\end{tabular}

$* *$ * Significance at $\mathrm{p}<0.01$ and $\mathrm{p}<0.05$, respectively. 
The number of earthworms used in the DMP varied, and was not sufficient to reach the inflection point of the curve, making it impossible to determine the maximum number that can be inoculated in the EUs to maximise production. However, high earthworm densities can lead to overpopulation, which has negative effects on the physical characteristics of the soil. This effect was described by Barros et al. (2004), who evaluated the impact of the mass invasion of Pontoscolex corethrurus in the Central Amazon, and observed that high densities of these earthworms increased the topsoil density and negatively affected plant growth.

The DMR did not differ between treatments (Table 3) $(p<0.05)$, with average values of 4.38 and $4.36 \mathrm{~g}$ obtained for the T1 and T5 treatments, respectively. The effects of the earthworms on root development are not yet fully known. Laossi et al. (2010) found that earthworms had similar effects during root development in legumes. Those authors also observed that a positive effect, namely the stimulation root growth, occurred in soils with low fertility.

Table 3. Regression analysis among earthworm number (Amynthas spp.), dry mass of plants (DMP)/dry mass of roots (DMR) ratio, and gall number of Meloidogyne javanica on tomato crop.

\begin{tabular}{cccc}
\hline $\begin{array}{c}\text { Treatments } \\
\text { (worms per pot) }\end{array}$ & $\begin{array}{c}\text { DMP } \\
\text { g plant }^{-1}\end{array}$ & $\begin{array}{c}\text { Ratio } \\
\text { DMP/DMR }\end{array}$ & $\begin{array}{c}\text { Galls } \\
\mathrm{n}^{\text {o }}\end{array}$ \\
\hline T1 (0) & $4.38^{\text {ns }}$ & $8.85^{\text {ns }}$ & $1030^{\text {ns }}$ \\
T2 (2) & $4.38^{\text {ns }}$ & $9.49^{\text {ns }}$ & $1006^{\text {ns }}$ \\
T3 (4) & $5.07^{\text {ns }}$ & $8.57^{\text {ns }}$ & $1152^{\text {ns }}$ \\
T4 (6) & $4.61^{\text {ns }}$ & $9.19^{\text {ns }}$ & $1158^{\text {ns }}$ \\
T5 $(8)$ & $4.36^{\text {ns }}$ & $10.27^{\text {ns }}$ & $1021^{\text {ns }}$ \\
CV $(\%)$ & 11.76 & 14.13 & 15.09 \\
\hline
\end{tabular}

ns - non-significant.

There were no significant differences in the ratio among the DMP and the DMR, with the values varying between 8.57 and 10.27 (Table 3). This may be explained by the physiological response of plants, since resources, water, and nutrients are not limited and there is no need for further development of the root system (BELL; SULTAN, 1999).

There was no significant difference in the number of galls between treatments, demonstrating that the plant-parasitic nematode, $M$. javanica, has a high capacity to parasitise the tomato roots. Under the conditions of the present study (earthworms Amynthas spp., tomato plants var. Santa Cruz Kada Paulista, phytonematode $M$. javanica), the earthworms were unable to suppress the population of nematodes that were inoculated in the soil.
The failure of earthworms to suppress nematodes, which was determined by the number of galls in the roots, can be interpreted in two different ways: feeding selectivity or inefficiency of the digestive system of worms. Nematodes, unlike fungi, are not considered an essential component of the earthworm diet (BONKOWSKI et al., 2000). Even when nematodes (or eggs and juveniles) are consumed, they may not be digested, because of the low efficiency of the earthworm digestive system (EDWARDS; BOHLEN, 1996), and instead remain alive within the casts.

The low number of worms detected at the end of the experiment (91 days) did not affect the formation of galls, because $M$. javanica infection occurs during the first 7 days after inoculation with the 
plant-parasitic nematode (CORTADA et al., 2008). Several authors have reported conflicting results regarding the effect of earthworms on the nematode population (DIONÍSIO et al., 2014; DOMÍNGUEZ et al., 2003; LAFONT et al., 2007; ILIEVAMAKULEC; MAKULEC, 2002). Therefore, this interaction remains poorly understood, and varies with soil type, and with the plant, nematode, and earthworm species.

Although the number galls was not reduced, decreased stress following nematode attachment to the plants was observed, as demonstrated through the DMP (Figure 7), indicating that the presence of earthworms in the soil was able to compensate for part of the damage caused by $M$. javanica. Lafont et al. (2007) observed a similar effect of Pontoscolex corethrurus on the growth of banana plants contaminated by burrowing nematodes (Radopholus similis), and attributed this effect to increased nitrogen bioavailability and greater uptake by plants, along with greater absorption of other elements, such as $\mathrm{Ca}$ and $\mathrm{Mg}$.

\section{Conclusions}

Under the experimental conditions evaluated, inoculation with earthworms of the Amynthas spp. was not able to suppress gall formation by nematodes in tomato crop.

The dry matter yield of tomato crop is favoured following inoculating with Amynthas spp. and independent of gall formation by the plant parasitic nematode $M$. javanica.

The microbial biomass carbon and metabolic quotient of soil are favoured by the action of Amynthas spp. in the presence of the phytoparasitic nematode $M$. javanica.

\section{Acknowledgements}

To CAPES and Diagnostic Center Marcos Enrietti for the support, to the Postgraduate
Program in Soil Science of the Federal University of Paraná, and to all teachers and students involved in this study.

\section{References}

AGHABABAEI, F.; RAIESI, F.; HOSSEINPUR, A. The combined effects of earthworms and arbuscular mycorrhizal fungi on microbial biomass and enzyme activities in a calcareous soil spiked with cadmium. Applied Soil Ecology, Amsterdam, v. 75, n. 1, p. 33-42, 2014.

AIRA, M.; MONROY, F.; DOMINGUEZ, J. Effects of two species of earthworms (Allolobophora spp.) on soil systems: a microfaunal and biochemical analysis. Pedobiologia, Amsterdam, v. 47, n. 5-6, p. 877-881, 2003.

- Eisenia fetida (Oligochaeta: Lumbricidae) modifies the structure and physiological capabilities of microbial communities improving carbon mineralization during vermicomposting of pig manure. Microbial Ecology, Cambridge, v. 54, n. 4, p. 662-671, 2007.

ALEF, K. Soil Respiration. In: ALEF, K.; NANNIPIERI, P. (Ed.). Methods in appllied soil microbiology and biochemistry. London: Academic Press Limited, 1995. p. 225-227.

AL-MALIKI, S.; SCULLION, J. Interactions between earthworms and residues of differing quality affecting aggregate stability and microbial dynamics. Applied Soil Ecology, Amsterdam, v. 64, n. 1, p. 56-62, 2013.

ANDERSON, J. P. E. Soil respiration. In: PAGE, A. L.; MILLER, R. H.; KEENEY, D. R. (Ed.). Methods of soil analysis. $2^{\text {th }}$ ed. Madison: Wisconsin: Soil Science Society of America, 1982. p. 831-866.

ANDERSON, J. P. E.; DOMSCH, K. H. A physiological method for the quantitative measurement of microbial biomass in soils. Soil Biology \& Biochemistry, Oxford, v. 10, n. 3, p. 215-221, 1978.

ANDERSON, T. H.; DOMSCH, K. H. The metabolic quotient for $\mathrm{CO}_{2}\left(q \mathrm{CO}_{2}\right)$ as a specific activity parameter to assess the effects of environmental conditions, such as $\mathrm{pH}$, on the microbial biomass of forest soils. Soil Biology \& Biochemistry, Oxford, v. 25, n. 3, p. 393-395, 1993.

BALOTA, E. L.; COLOZZI-FILHO, A.; ANDRADE, D. S.; HUNGRIA, M. Biomassa Microbiana e sua atividade em solos sob diferentes sistemas de preparo e sucessão de culturas. Revista Brasileira de Ciência do Solo, Viçosa, MG, v. 22, n. 1, p. 641-649, 1998. 
BARROS, E.; GRIMALDI, M.; SARRAZIN.; CHAUVEL, A.; MITJA, D.; DESJARDINS, T.; LAVELLE, P. Soil physical degradation and changes in macrofaunal communities in Central Amazon. Applied Soil Ecology, Amsterdam, v. 26, n. 2, p. 157-168, 2004.

BELAN, L. L.; ALVES, F. R.; COSTA, D. C.; FONSECA, S. O.; MORAES, W. B.; SOUZA, A. F.; JESUS, W. C. J. Efeitos de densidades crescentes de inóculo de Meloidogyne javanica no desenvolvimento vegetativo de genótipos de tomateiro cereja. Revista Trópica-Ciências Agrárias e Biológicas, Chapadinha, v. 5, n. 1, p. 22-30, 2011.

BELL, D. L.; SULTAN, S. E. Dynamic phenotypic plasticity for root growth in Polygonum: a comparative study. American Journal of Botany, St. Louis, v. 86, n. 6, p. 807-819, 1999.

BINET, F.; FAYOLLE, L.; PUSSARD, M. Significance of earthworms in stimulating soil microbial activity. Biology and Fertility of Soils, Florence, v. 27, n. 1, p. 79-84, 1998.

BONETTI, J. I. S.; FERRAZ, S. Modificações do método de Hussey e Barker para extração de ovos de Meloidogyne exigua de cafeeiro. Fitopatologia Brasileira, Brasília, v. 6, n. 1, p. 553-558, 1981.

BONKOWSKI, M.; CHENG, W.; GRIFFITHS, B. S.; ALPHEI, J.; SCHEU, S. Microbial-faunal interactions in the rhizosphere and effects on plant growth. European Journal of Soil Biology, Paris, v. 36, n. 1, p. 135-147, 2000 .

BOSSUYT, H.; SIX, J.; HENDRIX, P. F. Protection of soil carbon by microaggregates within earthworm casts. Soil Biology \& Biochemistry, Oxford v. 37, n. 2, p. 251258, 2005.

BROWN, G. G.; BAROIS, I.; LAVELLE, P. Regulation of soil organic matter dynamics and microbial activityin the drilosphere and the role of interactionswith other edaphic functional domains. European Journal of Soil Biology, Paris, v. 36, n. 3-4, p. 177-198, 2000.

BROWN, G. G.; HENDRIX, P. F.; BEARE, M. H. Influence of earthworms (Lumbricus rubellus) on sorghum litter processing and nitrogen mineralization in two Ultisols. Acta Zoologica Fennica, Helsinque, v. 196, n. 1, p. 55-59, 1995.

BROWN, G. G.; JAMES, S. W.; PASINI, A.; NUNES, D. H.; BENITO, N. P.; MARTINS, P. T.; SAUTTER, K. D. Exotic, peregrine, and invasive earthworms in Brazil: diversity, distribution, and effects on soils and plants. Caribbean Journal of Science, Puerto Rico, v. 42, n. 3, p. 339-358, 2006.
BURTELOW, A. E.; BOHLEN, P. J.; GROFFMAN, P. M. Influence of exotic earthworm invasion on soil organic matter, microbial biomass and denitrification potential in forest soils of the northeastern United States. Applied Soil Ecology, Amsterdam, v. 9, n. 1-3, p. 197202, 1998.

CHARCHAR, J. M.; ARAGÃO, F. A. S. Reprodução de Meloidogyne spp. em cultivares de tomate e pepino sob estufa plástica e campo. Nematologia Brasileira, Piracicaba, v. 29, n. 2, p. 243-249, 2005.

COELHO, L. F.; FREITAS, S. S.; MELO, A. M. T.; AMBROSANO, G. M. B. Interação de bactérias fluorescentes do gênero Pseudomonas e de Bacillus spp. com a rizosfera de diferentes plantas. Revista Brasileira de Ciência do Solo, Viçosa, MG, v. 31, n. 6, p. 14131420, 2007.

CORTADA, L.; SORRIBAS, F. J.; ORNAT, C.; KALOSHIAN, I.; VERDEJO-LUCAS, S. Variability in infection and reproduction of Meloidogyne javanica on tomato rootstocks with the $M i$ resistance gene. Plant Pathology, Malden, v. 57, n. 6, p. 1125-1135, 2008.

D'ANDRÉA, A. F.; SILVA, M. L. N.; CURI, N.; SIQUEIRA, J. O.; CARNEIRO, M. A. C. Atributos biológicos indicadores da qualidade do solo em sistemas de manejo na região do cerrado no sul do Estado de Goiás. Revista Brasileira de Ciência do Solo, Viçosa, MG, v. 26, n. 1, p. 913-923, 2002.

DE GRAAFF, M. A.; GROENIGEN, K. J. V.; SIX, J.; HUNGATE, B.; KESSEL, C. V. Interactions between plant growth and soil nutrient cycling under elevated $\mathrm{CO}$ : a meta-analysis. Global Change Biology, Malden, v. 12, n. 11, p. 2077-2091, 2006.

DECAËNS, T.; RANGEL, A. F.; ASAKAWA, N.; THOMAS, R. J. Carbon and nitrogen dynamics in ageing earthworm casts in grasslands of the eastern plains of Colombia. Biology and Fertility of Soils, Florence, v. 30, n. 1-2, p. 20-28, 1999.

DIONÍSIO, J. A.; LUNARDI, M. F.; MACEDA, A.; KUSDRA, J. F. Como reduzir o número de galhas de Meloidogyne paranaensis em raízes de tomateiro usando minhocas? Semina: Ciências Agrárias, Londrina, v. 35, n. 2, p. 781-786, 2014.

DOMÍNGUEZ, J.; PARMELEE, R. W.; EDWARDS, C. A. Interactions between Eisenia andrei (Oligochaeta) and nematode populations during vermicomposting. Pedobiologia, Amsterdam, v. 47, n. 1, p. 53-60, 2003.

DU, Y. L.; HE, M. M.; XU, M.; YAN, Z. G.; ZHOU, Y. Y.; GUO, G. L.; NIE, J.; WANG, L. Q.; HOU, H.; LI, F. S. Interactive effects between earthworms and maize 
plants on the accumulation and toxicity of soil cadmium. Soil Biology \& Biochemistry, Oxford, v. 72, n. 1, p. 193202, 2014.

EDWARDS, C. A.; BOHLEN, P. J. (Ed.). Biology and ecology of earthworms. 3. ed. London: Chapman and Hall, 1996. 426 p.

EISENHAUER, N.; SCHLAGHAMERKÝ, J.; REICH, P. B.; FRELICH, L. E. The wave towards a new steady state: Effects of earthworm invasion on soil microbial functions. Biological Invasions, Knoxville, v. 13, n. 10, p. 2191-2196, 2011.

EMPRESA BRASILEIRA DE PESQUISA AGROPECUÁRIA - EMBRAPA. Sistema brasileiro de classificação de solos. 3. ed. Rio de Janeiro: Embrapa Solos, 2013.

FREITAS, S. Rizobactérias promotoras do crescimento de plantas. In: SILVEIRA, A. P. D.; FREITAS, S. S. (Ed.). Microbiota do solo e qualidade. Campinas: Instituto Agronômico, 2007. p. 1-20.

GRAHAM, M. H.; HAYNES, R. J.; MEYER, J. H. Changes in soil chemistry and aggregate stability induced by fertilizer applications, burning and trash retention on a long-term sugarcane experiment in South Africa. Soil Biology \& Biochemistry, Oxford, v. 34, n. 1, p. 93-102, 2002.

GRISI, B. M. Método químico de medição da resporação edáfica: alguns aspectos técnicos. Ciência e Cultura, Campinas, v. 30, n. 1, p. 82-88, 1978.

HARTMAN, W. H.; RICHARDSON, C. J. Differential nutrient limitation of soil microbial biomass and metabolic quotients $\left(q \mathrm{CO}_{2}\right)$ : is there a biological stoichiometry of soil microbes? PLoS ONE, San Francisco, v. 8, n. 3, p. 1-14, 2013.

HÖGBERG, P.; READ, D. J. Towards a more plant physiological perspective on soil ecology. Trends in Ecology and Evolution, Cambridge, v. 21, n. 10, p. 548554, 2006.

HÖPER, H. Sustrate-induced respiration. In: BLOEM, D. H.; BENEDETTI, A. (Ed.). Microbiological methods for assessing soil quality. Wallingford: CABI Publishing, 2006. p. 84-92.

HUANG, Z.; WAN, X.; HE, Z.; YU, Z.; WANG, M.; HU, Z.; YANG, Y. Soil microbial biomass, community composition and soil nitrogen cycling in relation to tree species in subtropical China. Soil Biology \& Biochemistry, Oxford, v. 62, n. 1, p. 68-75, 2013.

ILIEVA-MAKULEC, K.; MAKULEC, G. Effect of the earthworm Lumbricus rubellus on the nematode community in a peat meadow soil. European Journal of Soil Biology, Paris, v. 38, n. 1, p. 59-62, 2002.

INSTITUTO BRASILEIRO DE GEOGRAFIA E ESTATÍSTICA - IBGE. Produção agrícola: levantamento sistemático da produção agrícola. Rio de Janeiro: IBGE, 2015. Disponível em: <ftp://ftp.ibge.gov.br/ Producao_\%5Bmensal\%5D/Fasciculo/lspa_201501. pdf>. Acesso em: 11 nov. 2015.

LAFONT, A.; RISÈDE, J. M.; LORANGERMERCIRIS, G.; CLERMONT-DAUPHIN, C.; DOREL, M.; RHINO, B.; LAVELLE, P. Effects of the earthworm Pontoscolex corethrurus on banana plants infected or not with the plant-parasitic nematode Radophulus similis. Pedobiologia, Amsterdam, v. 51, n. 4, p. 311-318, 2007.

LAOSSI, K. R.; GINOT, A.; NOGUERA, D.; BLOUIN, M.; BAROT, S. Earthworm effects on plant growth do not necessarily decrease with soil fertility. Plant and Soil, Dordrecht, v. 328, n. 1-2, p. 109-118, 2010.

LAVELLE, P.; BIGNELL, D.; LEPAGE, M.; WOLTERS, V.; ROGER, P.; INESON, P.; HEAL, O W.; DHILLION, $\mathrm{S}$. Soil function in a changing world: the role of invertebrate ecosystem engineers. European Journal of Soil Biology, Paris, v. 33, n. 4, p. 159-193, 1997.

LI, X.; FISK, M. C.; FAHEY, T. J.; BOHLEN, P. J. Influence of earthworm invasion on soil microbial biomass and activity in a northern hardwood forest. Soil Biology \& Biochemistry, Oxford, v. 34, n. 1, p. 19291937, 2002.

MARHAN, S.; LANGEL, R.; KANDELER, E.; SCHEU, S. Use of stable isotopes $\left({ }^{13} \mathrm{C}\right)$ for studying the mobilisation of old soil organic carbon by endogeic earthworms (Lumbricidae). European Journal of Soil Biology, Paris, v. 43, n. 1, p. S201-S202, 2007.

MOENS, M.; PERRY, R. N.; STARR, J. L. Meloidogyne species - a diverse group of novel and importante plant parasites. In: PERRY, R. N.; MOENS, M.; STARR, J. L. (Ed.). Root-knot nematodes. Wallingford: CABI Publishing, 2009. p. 1-18.

MÔNACO, A. P. A.; KRANZ, W. M.; GOMES, J. C.; SCHERER, A.; NAKAMURA, K. C.; MORITZ, M. P.; SANTIAGO, D. C. Reação de espécies de plantas daninhas a Meloidogyne incognita raças 1 e 3, a $M$. javanica e a $M$. paranaensis. Nematologia Brasileira, Piracicaba, v. 32, n. 4, p. 235-242, 2008.

MOREIRA, F. J. C.; FERREIRA, A. C. D. S. Controle alternativo de nematoide das galhas (Meloidogyne enterolobii) com cravo de defunto (Tagetes patula L.), incorporado ao solo. Holos, Natal, v. 31, n. 1, p. 99-110, 2015. 
MOREIRA, F. M. S.; SIQUEIRA, J. O. Microbiologia e biotecnologia do solo. 2. ed. Lavras: UFLA, 2006. 729 p.

MUMMEY, D. L.; RILLIG, M. C.; SIX, J. Endogeic earthworms differentially influence bacterial communities associated with different soil aggregate size fractions. Soil Biology \& Biochemistry, Oxford, v. 38, n. 7, p. 1608-1614, 2006.

NEVES, W. S.; FREITAS, L. G.; COSTA, M. D.; ALMEIDA, V. S.; FERRAZ, S. Controle de Meloidogyne javanica pelo uso de bactérias isoladas de solo biofumigado com resíduos de diferentes espécies de Brássicas. Nematologia Brasileira, Piracicaba, v. 33, n. 2, p. 132-138, 2009.

PARKIN, T. B.; BERRY, E. C. Microbial nitrogen transformations in earthworm burrows. Soil Biology \& Biochemistry, Oxford, v. 31, n. 13, p. 1765-1771, 1999.

PÔRTO, M. L.; ALVES, J. C.; DINIZ, A. A.; SOUZA, A. P.; SANTOS, D. Indicadores biológicos de qualidade do solo em diferentes sistemas de uso no Brejo Paraibano. Ciência e Agrotecnologia, Lavras, v. 33, n. 4, p. 10111017, 2009.

RADWAN, M. A.; FARRAG, S. A. A.; ABUELAMAYEM, M. M.; AHMED, N. S. Biological control of the root-knot nematode, Meloidogyne incognita on tomato using bioproducts of microbial origin. Applied Soil Ecology, Amsterdam, v. 56, n. 1, p. 58-62, 2012.

SANTOS, V. B.; CASTILHOS, D. D.; CASTILHOS, R. M. V.; PAULETTO, E. A.; GOMES, A. S.; SILVA, D. G. Biomassa, atividade microbiana e teores de carbono e nitrogênio totais de um planossolo sob diferentes sistemas de manejo. Revista Brasileira de Agrociência, Pelotas, v. 10, n. 3, p. 333-338, 2004.

SELDEN, P.; DUPONTE, M.; SIPES, B.; DINGES, K. Composting worms for Hawaii. College of Tropical Agriculture and Human Resources, Honolulu, v. HG-46, n. 1, p. 1-2, 2005.

SILVA JÚNIOR, J. M. T.; GOMES, V. F. F.; MENDES FILHO, P. F. Atividade microbiana e desenvolvimento do melão cultivado sob diferentes proporções de pó de coco. Revista Caatinga, Mossoró, v. 19, n. 4, p. 369-376, 2006.
SIMEK, M.; PIZL, V. Soil $\mathrm{CO}_{2}$ flux affected by Aporrectodea caliginosa earthworms. Central European Journal of Biology, Paris, v. 5, n. 3, p. 364-370, 2010.

SIMS, R. W.; GERARD, B. M. Earthworms. In: KERMACK, D. M.; BARNES, R. S. K. (Ed.). Synopses of the british fauna (new series). London: Field Studies Council, 1999. p. 8-169.

SNYDER, B. A.; BOOTS, B.; HENDRIX, P. F. Competition between invasive earthworms (Amynthas corticis, Megascolecidae) and native North American millipedes (Pseudopolydesmus erasus, Polydesmidae): effects on carbon cycling and soil structure. Soil Biology \& Biochemistry, Oxford, v. 41, n. 7, p. 1442-1449, 2009.

SOCIEDADE BRASILEIRA DE CIÊNCIA DO SOLO SBCS. Manual de adubação e de calagem para os estados do Rio Grande do Sul e Santa Catarina. 10. ed. Porto Alegre: Sociedade Brasileira de Ciência do Solo, 2004.

SOLLINS, P.; HOMANN, P.; CALDWELL, B. A. Stabilization and destabilization of soil organic matter: Mechanisms and controls. Geoderma, Amsterdam, v. 74, n. 1-2, p. 65-105, 1996.

STEPHENS, P. M.; DAVOREN, C. W. Influence of the earthworms Aporrectodea trapezoides and A. rosea on the disease severity of Rhizoctonia solani on subterranean clover and ryegrass. Soil Biology \& Biochemistry, Oxford, v. 29, n. 3-4, p. 511-516, 1997.

STOTZKY, G. Microbial respiration. In: BLACK, C. A. (Ed.). Methods of soil analysis. Madison, Wisconsin: American Society of Agronomy, 1965. p. 1550-1572.

YVAN, C.; STÉPHANE, S.; STÉPHANE, C.; PIERRE, B.; GUY, R.; HUBERT, B. Role of earthworms in regenerating soil structure after compaction in reduced tillage systems. Soil Biology \& Biochemistry, Oxford, v. 55, n. 1, p. 93-103, 2012.

ZHAO, Z. M.; ZHAO, G. Y.; YILIHAMU, Y.; LI, J. Y.; JUN, L. Contribution of root respiration to total soil respiration in a cotton field of Northwest China. Pedosphere, Beijing, v. 23, n. 2, p. 223-228, 2013. 